\title{
Regional estimates of reef carbonate dynamics and productivity using Landsat 7 ETM+, and potential impacts from ocean acidification
}

\author{
Christopher S. Moses ${ }^{1,3, *}$, Serge Andréfouët ${ }^{2}$, Christine J. Kranenburg ${ }^{1}$, \\ Frank E. Muller-Karger ${ }^{1,4}$
}

${ }^{1}$ University of South Florida, Institute for Marine Remote Sensing, 140 7th Avenue South, St. Petersburg, Florida 33701, USA

${ }^{2}$ Institut de Recherche pour le Développement (IRD), BP A5 - 98848 Nouméa cedex, New Caledonia

${ }^{3}$ Present address: Jacobs Technology, USGS/FISC, 600 Fourth Street South, St. Petersburg, Florida 33701, USA

${ }^{4}$ Present address: Univ. of Massachusetts Dartmouth, School for Marine Science and Technology (SMAST), 706 South Rodney French Blvd, New Bedford, Massachusetts 02744-1221, USA

\begin{abstract}
Using imagery at $30 \mathrm{~m}$ spatial resolution from the most recent Landsat satellite, the Landsat 7 Enhanced Thematic Mapper Plus (ETM+), we scale up reef metabolic productivity and calcification from local habitat-scale $\left(10^{-1}\right.$ to $\left.10^{0} \mathrm{~km}^{2}\right)$ measurements to regional scales $\left(10^{3}\right.$ to $\left.10^{4} \mathrm{~km}^{2}\right)$. Distribution and spatial extent of the North Florida Reef Tract (NFRT) habitats come from supervised classification of the Landsat imagery within independent Landsat-derived Millennium Coral Reef Map geomorphologic classes. This system minimizes the depth range and variability of benthic habitat characteristics found in the area of supervised classification and limits misclassification. Classification of Landsat imagery into 5 biotopes (sand, dense live cover, sparse live cover, seagrass, and sparse seagrass) by geomorphologic class is $>73 \%$ accurate at regional scales. Based on recently published habi-

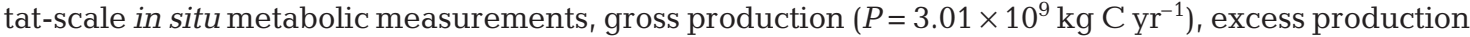
$\left(E=-5.70 \times 10^{8} \mathrm{~kg} \mathrm{C} \mathrm{yr}^{-1}\right)$, and calcification $\left(G=-1.68 \times 10^{6} \mathrm{~kg} \mathrm{CaCO}_{3} \mathrm{yr}^{-1}\right)$ are estimated over $2711 \mathrm{~km}^{2}$ of the NFRT. Simple models suggest sensitivity of these values to ocean acidification, which will increase local dissolution of carbonate sediments. Similar approaches could be applied over large areas with poorly constrained bathymetry or water column properties and minimal metabolic sampling. This tool has potential applications for modeling and monitoring large-scale environmental impacts on reef productivity, such as the influence of ocean acidification on coral reef environments.
\end{abstract}

KEY WORDS: Remote sensing $\cdot$ Corals $\cdot$ Carbon cycle $\cdot$ Millennium Coral Reef Map

Resale or republication not permitted without written consent of the publisher

\section{INTRODUCTION}

There is mounting evidence that global climate change and related ocean acidification will have serious impacts on marine calcifiers, including coral reefs (Smith \& Buddemeier 1992, Kleypas et al. 2001, 2006, Walther et al. 2002, Hughes et al. 2003). More specifically, increases in atmospheric and oceanic $\mathrm{pCO}_{2}$ cause changes in the carbonate chemistry of surface ocean waters in the form of decreases in $\mathrm{pH}$ (ocean acidification) and reduced carbonate ion concentration
$\left[\mathrm{CO}_{3}{ }^{-2}\right]$ (Zeebe \& Wolf-Gladrow 2003, Feely et al. 2004). This reduces the aragonite $\left(\mathrm{CaCO}_{3}\right)$ saturation state $\left(\Omega_{\text {arag }}\right)$, making it more difficult for corals to accrete their massive aragonite skeletons (Gattuso et al. 1998a, Kleypas et al. 1999, Gattuso \& Buddemeier 2000, Orr et al. 2005, Fine \& Tchernov 2007). While decreases in $\Omega_{\text {arag }}$ and $\Omega_{\text {calcite }}$ are known to reduce the carbonate production of corals and coralline algae (Orr et al. 2005, Kuffner et al. 2007), the magnitude of impact may not be the same for all carbonate producing reef organisms. 
Estimates by Ware et al. (1992) indicate that reefs are sources of atmospheric $\mathrm{CO}_{2}$, globally accounting for 0.02 to $0.08 \mathrm{Gt}\left(1 \mathrm{Gt}=10^{12} \mathrm{~kg}\right) \mathrm{yr}^{-1}$. This may seem somewhat counter-intuitive, but calcification actually releases $\mathrm{CO}_{2}$. Precipitation of carbonate in reefs results in sequestering carbon in the $\mathrm{CaCO}_{3}$ framework of the reef over geologic times, but in the short term, the precipitation of calcium carbonate drives a change in $\mathrm{pH}$ that results in a release of $\mathrm{CO}_{2}$ into solution:

$$
\mathrm{Ca}+2 \mathrm{HCO}_{3} \leftrightarrow \mathrm{CaCO}_{3}+\mathrm{H}_{2} \mathrm{O}+\mathrm{CO}_{2(\mathrm{aq})}
$$

Many previous estimates of the contribution of reefs to the global carbon cycle are rapidly becoming outdated in the face of global decline of coral reefs (Hoegh-Guldberg 1999, Gardner et al. 2003, Pandolfi et al. 2003), more accurate mapping of global reef extent (which indicates productive areas have been overestimated; Andréfouët et al. 2006), and global climate changes (Hoegh-Guldberg 2005). While valuable, the most cited production estimates for habitats or community types from significant early studies (Smith \& Kinsey 1976, Kinsey 1978, 1983, 1985, Atkinson \& Grigg 1984) represent a relatively narrow range of community types, years, and geographic distribution (e.g. minimal Caribbean representation). The result is that the metabolism and carbonate production, as well as $\mathrm{CO}_{2}$ air-sea flux, of reefs remains poorly constrained across global reef distribution and under changing environmental circumstances.

The amount of carbonate mineral precipitation $(G)$ can be a measure of reef community performance or 'health' (Kinsey 1985), particularly in the context of increasing ocean acidification. Additionally, the net metabolism of a given reef zone or substrate type can be accounted for by the balance of productivity, or gross photosynthetic carbon fixation $(P)$, and respiration $(R)$. The $P: R$ ratio is also frequently used as one measure of excess production $(E)$ (Kinsey 1985). Kinsey (1983) established a set of reef metabolic end members, including at one end $100 \%$ coral-algal hard substrate with values of $P=20 \mathrm{~g} \mathrm{C} \mathrm{m}^{-2} \mathrm{~d}^{-1}$ and $G=10 \mathrm{~g}$ $\mathrm{CaCO}_{3} \mathrm{~m}^{-2} \mathrm{~d}^{-1}$. The opposite end member was $100 \%$ sand and rubble with values of $P=1 \mathrm{~g} \mathrm{C} \mathrm{m}^{-2} \mathrm{~d}^{-1}$ and $G=0.5 \mathrm{~g} \mathrm{CaCO}_{3} \mathrm{~m}^{-2} \mathrm{~d}^{-1}$. These metabolic parameters are assumed to have additive properties when scaling up with remote sensing (Atkinson \& Grigg 1984, Andréfouët \& Payri 2001, Vecsei 2004).

Despite the general agreement on reefs as sources of $\mathrm{CO}_{2}$ (Ware et al. 1992, Gattuso et al. 1996, 1998b, Suzuki et al. 1997), there is evidence that certain reefs, or parts thereof, are sinks for atmospheric $\mathrm{CO}_{2}$ (Kayanne et al. 1995, Ikeda et al. 1997, Yates \& Halley 2006). Further complicating the issue, recent direct measurements on Moloka'i (Hawai'i, USA) indicate that a reef may operate simultaneously as both a source and a sink in patchy patterns related to biological zonation (Yates \& Halley 2006). These air-sea fluxes can be investigated using either direct measurements of $\mathrm{pCO}_{2}$ or budgetary approaches based on community metabolism data $\left(\mathrm{pH}\right.$, dissolved $\mathrm{O}_{2}$, and total alkalinity measurements). However, due to differences in methods and reef habitat classification schemes, it is difficult to compare many of these results.

Previous works on scaling up coral reef carbonate metabolic parameters using remote sensing techniques have been somewhat limited in geographic scope, from $\sim 0.5$ to $\sim 35 \mathrm{~km}^{2}$ (Brock et al. 2006 and Andréfouët \& Payri 2001, respectively). These scales are too small to provide management with necessary regional-scale decision support in the face of ocean acidification. Production was also scaled up over about $700 \mathrm{~km}^{2}$ at French Frigate Shoals (Hawai'i, USA) (Atkinson \& Grigg 1984), approaching the necessary scale for management implications, but becoming outdated in the context of reef decline. Prior remote sensing work on reef metabolic parameters has also been limited to very high resolution sensors with horizontal resolutions of $20 \mathrm{~m}$ or less (Andréfouët \& Payri 2001, Brock et al. 2006) which have relatively small 'footprints,' making it expensive to cover regional scales.

Here, we (1) demonstrate the ability of Landsat 7 Enhanced Thematic Mapper Plus (ETM+) satellite (30 $\mathrm{m}$ resolution) to accurately classify reef biotopes in order to extrapolate limited in situ reef metabolic values to a regional scale for the North Florida Reef Tract (NFRT), an area of $2711 \mathrm{~km}^{2}$ (Fig. 1); and (2) show that the NFRT is in a state of net dissolution and acts as a carbon sink at regional scales. These results provide important estimates of metabolic functioning and carbonate precipitation over spatial scales relevant to ecosystem-based management and models of regional responses to ocean acidification.

\section{MATERIALS AND METHODS}

Location. The Florida Keys and surrounding waters are managed and studied by several levels of state and federal government agencies. The Florida Keys are a chain of low islands extending nearly $400 \mathrm{~km}$ from the southeastern tip of Florida to the south and west of Florida Bay. Based on geomorphology and exchange with Florida Bay, the Keys are divided into the Upper, Middle, and Lower Keys. In the Upper Keys and NFRT, the zonation proceeds eastward (seaward) from the islands with a broad, shallow seagrass flat, followed by Hawk Channel with seagrass and patch reefs, then shallowing again to the barrier reef complexes $\sim 5 \mathrm{~km}$ offshore. The Upper Keys and NFRT have a docu- 

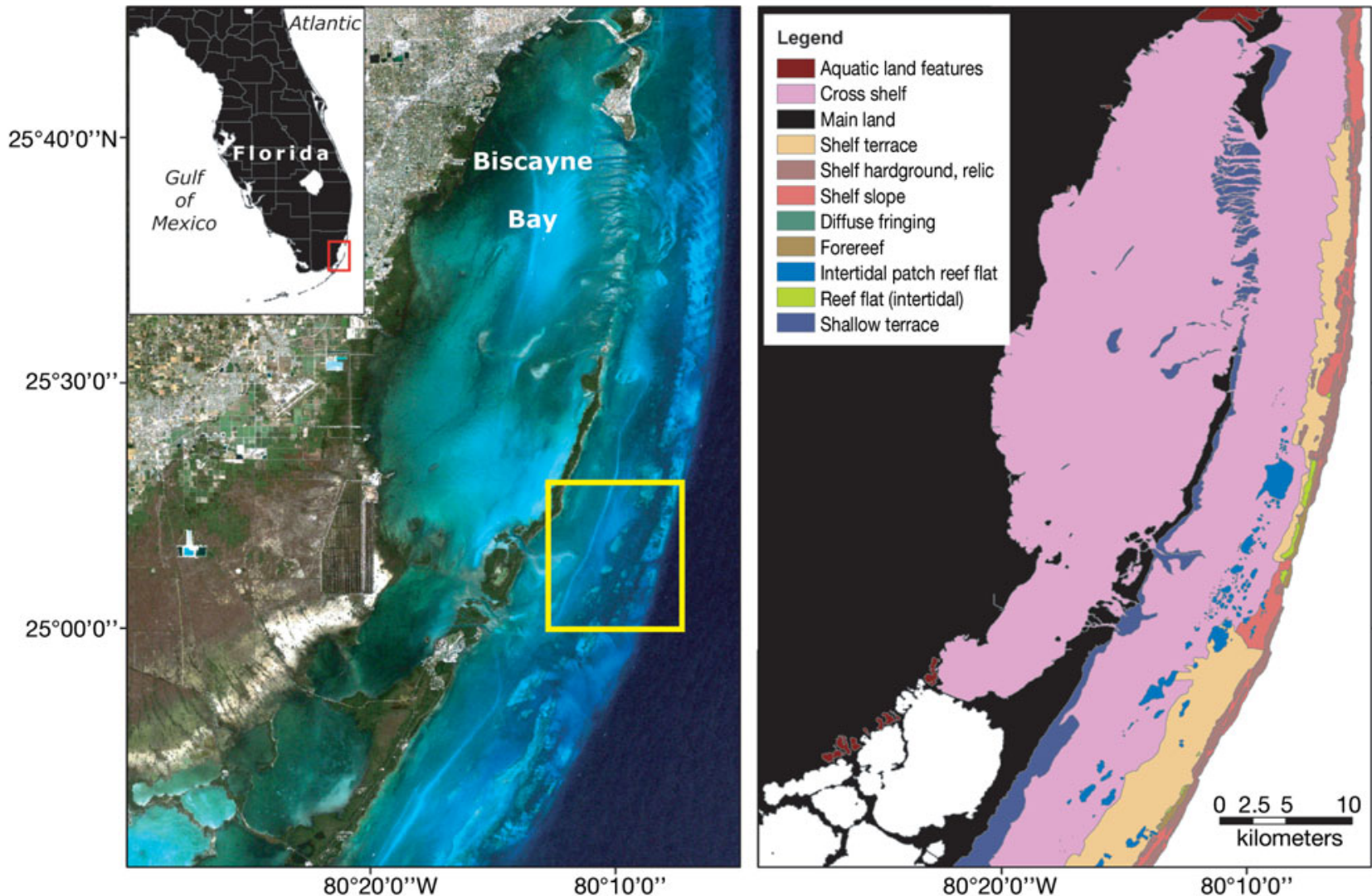

Fig. 1. (Left) Landsat 7 Enhanced Thematic Mapper Plus (ETM+) image of the North Florida Reef Tract (NFRT) (path 015, row 042) acquired on 5 February 2000. Yellow box indicates extent of the IKONOS image used for validation by proxy. (Right) Millennium Coral Reef Map of the NFRT. Colors each represent a different geomorphologic reef class. The 3 geomorphologic classes discussed in this article represent those with the highest coverage areas in the NFRT by area

mented record of decline in reef health (Dustan et al. 2001, Gardner et al. 2003, CREMP 2005, Palandro et al. 2008). The Florida Keys have also been the subject of particular interest in the use of remote sensing for mapping reef habitats (Torres-Pulliza 2004), and documenting change in reef environments (Andréfouët et al. 2001, Dustan et al. 2001, Palandro et al. 2003a,b).

\section{Carbonate and metabolic parame-} ters, and scaling. This project applies values for reef carbonate precipitation and carbon metabolism parameters measured in situ by Yates \& Halley (2003). In particular, we use that subset of Yates \& Halley (2003) values reported in Brock et al. (2006) for the same habitats (biotopes), but a much smaller area of the NFRT (Table 1). The metabolic values were collected using a unique in situ mesocosm, the Submersible Habitat for Analyzing Reef Quality (SHARQ) that is operated by the US Geological Survey (Yates \& Hal- ley 2003). Brock et al. (2006) reported values for $P_{1} R_{\text {, }}$ $P: R, E$, and $G$ for 4 reef habitat classes (biotopes) common to the NFRT: sand, dense live substrate, sparse live substrate, and seagrass. For this study, we adopted those biotopes and their definitions, and added a sparse seagrass biotope defined here as a linear mix of $20 \%$ seagrass and $80 \%$ sand (Table 1 ).

Table 1. Carbon and carbonate production values for each of the 5 biotopes used in this assessment

\begin{tabular}{|c|c|c|c|c|c|}
\hline Biotope & $\begin{array}{c}P(\mathrm{~g} \mathrm{C} \\
\left.\mathrm{m}^{-2} \mathrm{~d}^{-1}\right)\end{array}$ & $\begin{array}{c}R(\mathrm{~g} \mathrm{C} \\
\left.\mathrm{m}^{-2} \mathrm{~d}^{-1}\right)\end{array}$ & $\begin{array}{c}E(g \mathrm{C} \\
\left.\mathrm{m}^{-2} \mathrm{~d}^{-1}\right)\end{array}$ & $P: R$ & $\begin{array}{c}G\left(\mathrm{~g} \mathrm{CaCO}_{3}\right. \\
\left.\mathrm{m}^{-2} \mathrm{~d}^{-1}\right)\end{array}$ \\
\hline Sand $^{\mathrm{a}}$ & 1.76 & 1.96 & -0.20 & 0.90 & 0.11 \\
\hline Seagrass $^{a}$ & 2.88 & 3.32 & -0.44 & 0.87 & -0.19 \\
\hline Sparse seagrass $^{\mathrm{b}}$ & 1.98 & 2.23 & -0.25 & 0.89 & 0.05 \\
\hline Dense live substrate $^{a}$ & 6.43 & 8.09 & -1.66 & 0.79 & 1.29 \\
\hline Sparse live substrate ${ }^{a}$ & 4.23 & 5.31 & -1.08 & 0.80 & -0.04 \\
\hline
\end{tabular}


Dense live substrate, as defined on NFRT patch reefs for metabolic parameters by Brock et al., (2006), consisted of an average of $\sim 7 \%$ live hermatypic coral (scleractinian plus hydrocoral) cover, $27 \%$ macroalgae (calcareous and fleshy), about $10 \%$ gorgonians, and $21 \%$ bare hardbottom. Sparse live substrate represents areas with the same components as dense live substrate, but $\geq 50 \%$ bare hard bottom. The sand and seagrass biotopes represent unconsolidated carbonate sands of varying thicknesses, and dense $(\geq 50 \%)$ seagrass (generally Thalassia testudinum in the NFRT), respectively.

For each of the 3 Millennium Coral Reef Map (MCRM) geomorphologic classes, we used roughly equal area regions of interest (ROIs) to train the supervised image classification over confirmed locations for each biotope. In the case of the cross-shelf and shelfterrace MCRM classes, we were able to apply all 5 biotopes. However, in the case of the MCRM-patch reef class, there were no pixels with confirmed sparse seagrass, so that biotope was not included in estimates for the patch reef class.

Production on coral reefs is assumed to be an additive emergent process (Atkinson \& Grigg 1984, Hatcher 1997), such that the whole is equal to the sum of the parts. For example, the contribution of a reef class to $P$ for the whole of the NFRT is itself dependent on the sum of its 5 biotopes (sand, dense live substrate, sparse live substrate, sparse seagrass, and seagrass). The process is additive such that the measured value for $P\left(\mathrm{~g} \mathrm{C} \mathrm{m}^{-2} \mathrm{~d}^{-1}\right)$ for each biotope (Table 1) is multiplied by the fractional area covered by that biotope $\left(F_{\text {biotope }}\right)$. It follows as:

$$
\begin{aligned}
& P_{\mathrm{NFRT}}=\left(F_{\text {sand }} \times P_{\text {sand }}\right) \\
& +\left(F_{\text {dense live }} \times P_{\text {dense live }}\right)+\left(F_{\text {sparse live }} \times P_{\text {sparse live }}\right) \\
& +\left(F_{\text {seagrass }} \times P_{\text {seagrass }}\right)+\left(F_{\text {sparse SG }} \times P_{\text {sparse SG }}\right)
\end{aligned}
$$

This results in the production for the entire NFRT of $P=3.03 \mathrm{~g} \mathrm{C} \mathrm{m}^{-2} \mathrm{~d}^{-1}$ (Table 2). A similar method was also applied for the MCRM class estimates. Each MCRM class was evaluated for $P, R, E, P: R$, and $G$ using the same process as above. Thus, $P\left(\mathrm{~g} \mathrm{C} \mathrm{m}^{-2} \mathrm{~d}^{-1}\right)$ for each biotope is multiplied by the fractional area covered by that biotope $\left(F_{\text {biotope }}\right)$ in the MCRM class (for example the patch reef class, $P_{\text {patch reef }}$ ). Then $P_{\text {patch }}$ reef can be additively scaled over the fractional area represented by the MCRM patch reef class ( $F_{\text {patch reef }}$ ) in the NFRT to arrive at $P_{\text {NFRT }}$.

To estimate the impacts from projected ocean acidification, a simple reduction of biogenic carbonate production was applied to $G_{\text {biotope }}$ and scaled up to $G_{\text {NFRT }}$ in the same manner as the example above. The addi- tive model used here did not account for dynamic environmental complexities. However, future work could be coupled with models of water retention time, sea surface temperature (SST), and salinity for more accurate estimates concerning the impacts from ocean acidification.

Satellite images. The Landsat 7 ETM+ was launched by NASA in April 1999, and acquired reliable imagery globally until it developed a scan-line corrector problem in June 2003. Landsat 7 ETM+ images are about $180 \times 180 \mathrm{~km}$, with a multispectral pixel resolution of $30 \mathrm{~m}$ across 4 spectral bands that are useful for work in coral reef areas: blue (450 to $520 \mathrm{~nm}$ ), green (530 to $610 \mathrm{~nm})$, red (630 to $660 \mathrm{~nm})$, and near infra-red (780 to $900 \mathrm{~nm}$ ). Landsat imagery has demonstrated its value in multiple coral reef applications (Andréfouët et al. 2001, Dustan et al. 2001, Capolsini et al. 2003, Ouillon et al. 2004). A cloud-free Landsat 7 ETM+ image covering all of the south Florida, from Path 015, Row 042, acquired on 5 February 2000, was used for this project. This image was cropped to $2711 \mathrm{~km}^{2}$ of shallow marine habitat defined here as the NFRT (Fig. 1).

An IKONOS image covering about $125 \mathrm{~km}^{2}$ just east of Ceasar's Creek and Elliot Key in Biscayne National Park (Florida, USA), acquired on 18 March 2001, was used to carefully direct and validate the classification of the Landsat image by taking advantage of its high resolution $(4 \mathrm{~m})$ which allows the sub-Landsat pixel identification of the habitats of interest (Mumby \& Edwards 2002, Andréfouët et al. 2003). The IKONOS satellite is operated privately by GeoEye ${ }$, and uses 4 spectral bands close to the Landsat 7 ETM+ bands, but with $4 \mathrm{~m}$ pixel resolution. The corporate nature of IKONOS naturally makes the imagery more expensive to acquire than Landsat imagery, but it has proven valuable for reef studies in several applications (Andréfouët et al. 2003, Capolsini et al. 2003, Palandro et al. 2003a, Brock et al. 2006).

MCRM classes. The NASA-funded MCRM (Andréfouët et al. 2006) uses the global coverage of Landsat 7 ETM+ satellite imagery to create a global coral reef map with $30 \mathrm{~m}$ resolution and $\sim 800$ geomorphologic reef classes at the finest level of thematic resolution, 
many of which can be found worldwide. However, most large reef structures (barrier, fringing, atoll, bank, shelf reef, etc.) include a limited number of geomorphologic classes, generally limited to a maximum of $~ 30$ classes. Three MCRM classes in the NFRT were tested for their ability to scale up carbon and carbonate metabolic measurements. Classes included: \#568 'continental patch complex/intra-seas patch reef complex/ reef flat' (hereafter: patch reef), \#781 'shelf marginal structure/shelf terrace/shelf terrace' (shelf terrace), and \#793 'cross shelf/cross shelf/cross shelf' (cross shelf) (Fig. 1). The naming convention listed above represents level 2/level 3/level 4 classes of a 5 level hierarchical classification scheme used for the MCRM classes, with the first level for all cases here being 'continental,' and the numbers being the unique level 5 class identifier (Andréfouët et al. 2006).

The patch reef class represents a discontinuous area landward of the outer reef flat dominated by individual or coalescing patch reefs, with high relief (often subpixel) on the order of 2 to $3 \mathrm{~m}$ in this area. The shelf terrace class is a nearly continuous, reef-parallel terrace immediately landward of the reef flat with an average depth of 6 to $7 \mathrm{~m}$, and a width of 2 to $5 \mathrm{~km}$. The 'cross shelf' class is the broad, mid-depth $(\sim 3 \mathrm{~m}$ average depth), gently concave, low-relief geomorphologic class, including a deeper channel where most of the patch reef occurs, which spans most of the area between the coast and the shelf terrace. The other MCRM classes present in the NFRT, such as shelf slope, shelf hardground, and reef flat were not included in this study because of the absence of reliable carbon and carbonate production values for biotopes found in those geomorphologic classes in this region.

In addition to being found in the NFRT, the MCRM classes reported on in this project are found elsewhere in the Caribbean, providing the possibility for scaling up over broad ranges beyond the scope of this report. For instance, the cross shelf class (\#793) is abundant in Mesoamerica, Cuba, Nicaragua, and the entire range of the Florida Keys. Shelf terrace (\#781) is found throughout the Upper, Middle, and Lower Florida Keys, north and western Cuba, Jamaica, and a few areas of the Dominican Republic. Patch reefs (class \#568) are found throughout the Caribbean.

Image interpretation, classification, and validation. All image classification and validation was performed using the ENVI software package (v4.3). The Landsat 7 ETM+ image was classified using ROIs defined within each MCRM class. Working within each MCRM class limits the spectral confusion due to diversity of habitat and variability of depth. Areas were shallow and working by geomorphologic class minimizes the necessity of depth correction techniques (Wabnitz et al. 2008). Thus, no water column correction was performed. Fur- thermore, by not correcting for the water column, we were able to test the possibility that this method could be applied over a region with unknown water column properties and imprecisely known bathymetry. It can be safely assumed that the biotopes classified in this work did not significantly vary in space or condition in the 13 mo between the Landsat 7 ETM+ and IKONOS images (Palandro et al. in press). No hurricanes or tropical storms passed within $100 \mathrm{~km}$ of the study area during that time (Franklin et al. 2001).

We tested the classifications and resulting carbonate estimations for sensitivity to variances in training ROIs. For each of the 3 MCRM geomorphologic classes, the training pixels and validation pixels were rotated to create 4 sets of training ROIs. Each of those 4 sets of training ROIs were then run through each of 3 supervised classifications: Minimum Distance, Maximum Likelihood, and Mahalanobis Distance.

Landsat image classification was validated by proxy using the IKONOS image and by in situ data compiled from published (CREMP 2005, Marks 2007) and unpublished sources in the same time interval as the imagery (2000 to 2002). Different supervised classification algorithms were tested and inspected for accuracy. Spectral separability between biotopes was evaluated using the transformed divergence (TD) scores generated in ENVI. TD ranges from 0 to 2, where 0 indicates complete spectral similarity and 2 indicates completely distinct spectra (Jensen 2004). TD values between 1.7 to 1.9 are considered fairly good for separability and $>1.9$ is considered excellent separability (Jensen 2004). For objective validation, a total of 250 randomly selected points were chosen across all geomorphologic classes (patch reef, shelf terrace, and cross shelf) and distributed proportionally to the area represented by that class.

\section{RESULTS AND DISCUSSION}

\section{Scaling up local measurements to reliable regional estimates}

The approach to regional estimation of benthic carbonate and carbon metabolic parameters reported here appears to be robust over this regional scale. Despite an increase in scale of almost 4 orders of magnitude $\left(10^{3.7}\right)$ over the working area of Brock et al. (2006), values for gross photosynthetic production and respiration were very similar (Table 2). However, the value for $G$ reported across the larger area is notably different from that reported by Brock et al. (2006).

The overall performance of Landsat image classification was high, even in areas such as the patch reef class, which often have sub-pixel biotope variability (Fig. 2). This agrees well with previous applications of 


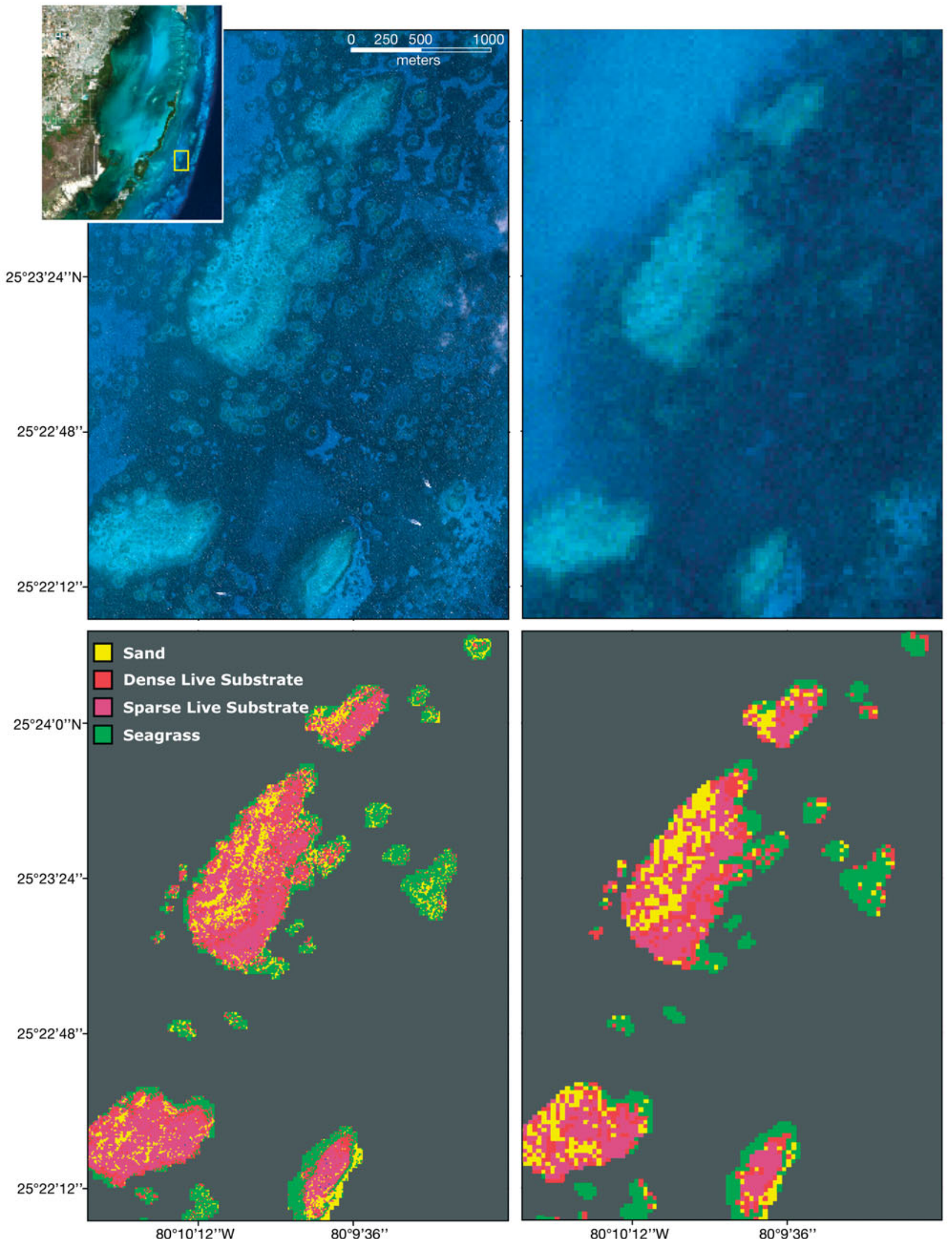

Fig. 2. Comparison of images (top) and supervised classification (bottom) of the patch reef class for IKONOS (left) and Landsat 7 Enhanced Thematic Mapper Plus (ETM+) (right). The differences shown between these classifications are negligible at regional scales because of the proportionality of the classes 
Landsat ETM+ imagery in reef environments using 5 or fewer classes (Torres-Pulliza 2004). Spectral class separation between the biotopes was generally good within each geomorphologic class, with $68 \%$ of transform divergence values $>1.80$. The lowest transform divergence value (0.63) was between shallower (6 to $7 \mathrm{~m}$ ) dense live substrate and deeper (9 to $11 \mathrm{~m}$ ) sparse live substrate in the shelf terrace class. Landsat classifications tended to overestimate sand coverage by comparison with IKONOS, which was likely caused by the relatively high brightness of sub-pixel areas of sand skewing the pixel classification towards sand.

Validation of Landsat 7 ETM+ image classification by proxy from IKONOS revealed high classification accuracy. Over the entire NFRT, the overall classification accuracy of combined geomorphologic classes was $86.2 \%$. Within the cross shelf class, the largest by area, pixels were correctly classified $88 \%$ of the time with most classification errors occurring between the sparse seagrass and seagrass biotopes. The shelf terrace class is the most spatially complex geomorphologic zone studied here and has high spatial variability on the scale of $10^{1}$ to $10^{2} \mathrm{~m}$. Shelf terrace biotopes were correctly classified $73 \%$ of the time, with errors predominantly between the seagrass and sparse seagrass due to the high spatial variability of seagrass beds on the shelf terrace. The patch reef class was classified correctly $83 \%$ of the time, with misclassification errors evenly distributed between seagrass, sparse live substrate, and dense live substrate. The even distribution in the error within the patch reef class probably resulted from the high number of mixed pixels that resulted from the spatial variability of classes at scales of $10^{0}$ to $10^{1} \mathrm{~m}$. Across all 3 geomorphologic classes, the sand biotope was correctly classified $100 \%$ of the time, while sparse live substrate was the most commonly misclassified (53.8\% correct; Table 3).

The MCRM geomorphologic classes proved to be able to serve as proxies for percent biotope composition, and thus carbon and carbonate production over regional scales with the 5 biotopes used here (Table 4). When trained with 4 different sets of ROIs and subjected to 3 different classification algorithms to test sensitivity of the scaling exercise to different training pixels and different supervised classification algorithms, the 3 MCRM classes used here displayed a degree of stability in estimated production and calcification values (Fig. 3). Sand was easiest to identify by visual interpretation, but returned the widest variability in classification accuracy, likely due to the broad spectrum in the green and blue bands associated with sand across a range of depths. The Maximum Likelihood supervised classification algorithm using the default settings and ROIs that were trained independently within each of the 3 MCRM classes investigated here yielded the

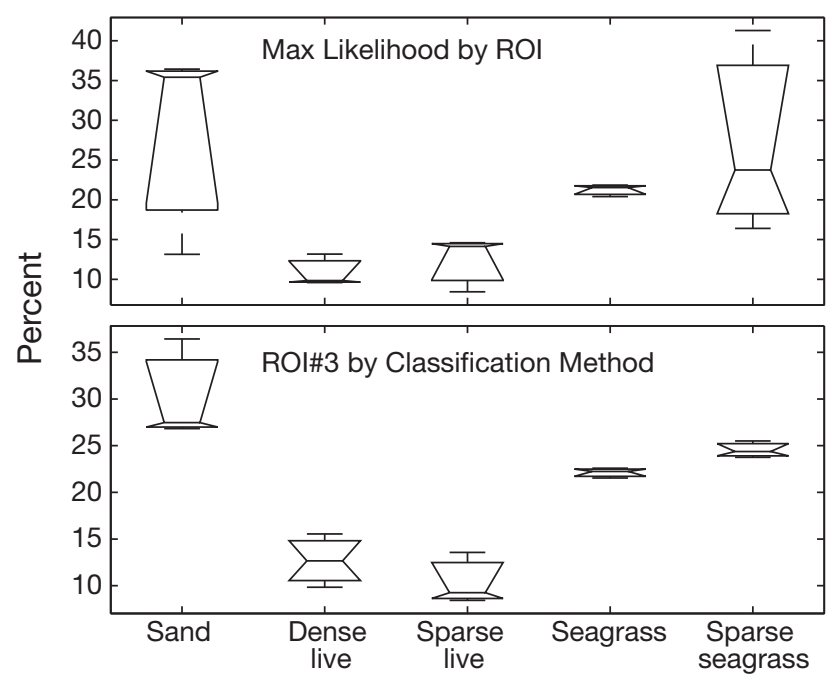

Fig. 3. Classification sensitivity analysis. (Top) Variability of results from a supervised Maximum Likelihood classification based on training by 4 different sets of regions of interest (ROIs). (Bottom) Range of results from 3 different supervised classifications using ROI set \#3 for each. All results here are for the shelf terrace class, but this was replicated for each Millenium Coral Reef Map geomorphologic class. The central line and notch indicate the median, the ends of the box mark the 25th and 75th percentiles, and the whiskers mark the full range of data points not considered outliers

Table 3. Error matrix for classification of biotopes from Landsat imagery. DLS = dense live substrate; SLS = sparse live substrate; $\mathrm{SG}=$ seagrass; $\mathrm{SSG}=$ sparse seagrass

\begin{tabular}{|lccccc|}
\hline & \multicolumn{5}{c|}{ Classified as $(\%)$} \\
\cline { 2 - 6 } & DLS & SLS & SG & SSG & Sand \\
\hline DLS & $\mathbf{6 6 . 7}$ & 3.7 & 25.9 & 3.7 & 0 \\
SLS & 0 & $\mathbf{5 3 . 8}$ & 23.1 & 23.1 & 0 \\
SG & 1.3 & 0 & $\mathbf{8 4 . 2}$ & 14.5 & 0 \\
SSG & 0 & 0 & 0 & $\mathbf{9 2 . 9}$ & 7.1 \\
Sand & 0 & 0 & 0 & 0 & $\mathbf{1 0 0}$ \\
\hline
\end{tabular}

Table 4. Estimated regional metabolic values for the 3 Millenium Coral Reef Map (MCRM) geomorphologic classes assessed in the North Florida Reef Tract (NFRT)

\begin{tabular}{|c|c|c|c|c|c|}
\hline $\begin{array}{l}\text { MCRM } \\
\text { Class }\end{array}$ & $\begin{array}{c}P(\mathrm{~g} \mathrm{C} \\
\left.\mathrm{m}^{-2} \mathrm{~d}^{-1}\right)\end{array}$ & $\begin{array}{c}R\left(\mathrm{~g} \mathrm{C}^{-2}\right. \\
\left.\mathrm{m}^{-2} \mathrm{~d}^{-1}\right)\end{array}$ & $\begin{array}{c}E\left(g_{C} \mathrm{C}\right. \\
\left.\mathrm{m}^{-2} \mathrm{~d}^{-1}\right)\end{array}$ & $P: R$ & $\begin{array}{c}G\left(\mathrm{~g} \mathrm{CaCO}_{3}\right. \\
\left.\mathrm{m}^{-2} \mathrm{~d}^{-1}\right)\end{array}$ \\
\hline $\begin{array}{l}\text { Intra-seas patch } \\
\text { reef complex }(\# 568)\end{array}$ & $\begin{array}{c}3.84 \\
( \pm 0.11)\end{array}$ & $\begin{array}{c}4.67 \\
( \pm 0.13)\end{array}$ & -0.84 & 0.84 & $\begin{array}{c}0.30 \\
( \pm 0.01)\end{array}$ \\
\hline Shelf terrace (\#781) & $\begin{array}{c}3.46 \\
( \pm 0.29)\end{array}$ & $\begin{array}{c}4.19 \\
( \pm 0.36)\end{array}$ & -0.73 & 0.83 & $\begin{array}{c}0.25 \\
( \pm 0.02)\end{array}$ \\
\hline Cross shelf (\#793) & $\begin{array}{c}2.90 \\
( \pm 0.05)\end{array}$ & $\begin{array}{c}3.43 \\
( \pm 0.06)\end{array}$ & -0.53 & 0.85 & $\begin{array}{c}-0.07 \\
( \pm 0.00)\end{array}$ \\
\hline
\end{tabular}


highest classification accuracy (Fig. 4). It could be suggested that if 4 to 5 appropriate biotopes are classified with high accuracy, the resulting carbon and carbonate production values for that MCRM class (Table 4) would allow a good first approximation of the production values wherever that class is found regionally.

In a previous multi-sensor comparison for coral reef habitat mapping (Torres-Pulliza 2004), a small section of the NFRT was classified into a total of 10 biotopes, and seagrass habitats alone were classified into 5 different categories. On a Pacific fringing barrier reef, Andréfouët \& Payri (2001) scaled up metabolic values using $20 \mathrm{~m}$ resolution SPOT satellite imagery and classified the image into 9 reef biotopes. Accurately classifying such a high number of biotopes becomes increasingly impractical over regional scales and results in decreasing classification accuracy at reef scales (Andréfouët et al. 2003). Also, at the $30 \mathrm{~m}$ resolution of Landsat ETM+ imagery, the higher numbers of classes would often be covered within a single mixed pixel. The broad definitions of the biotopes as

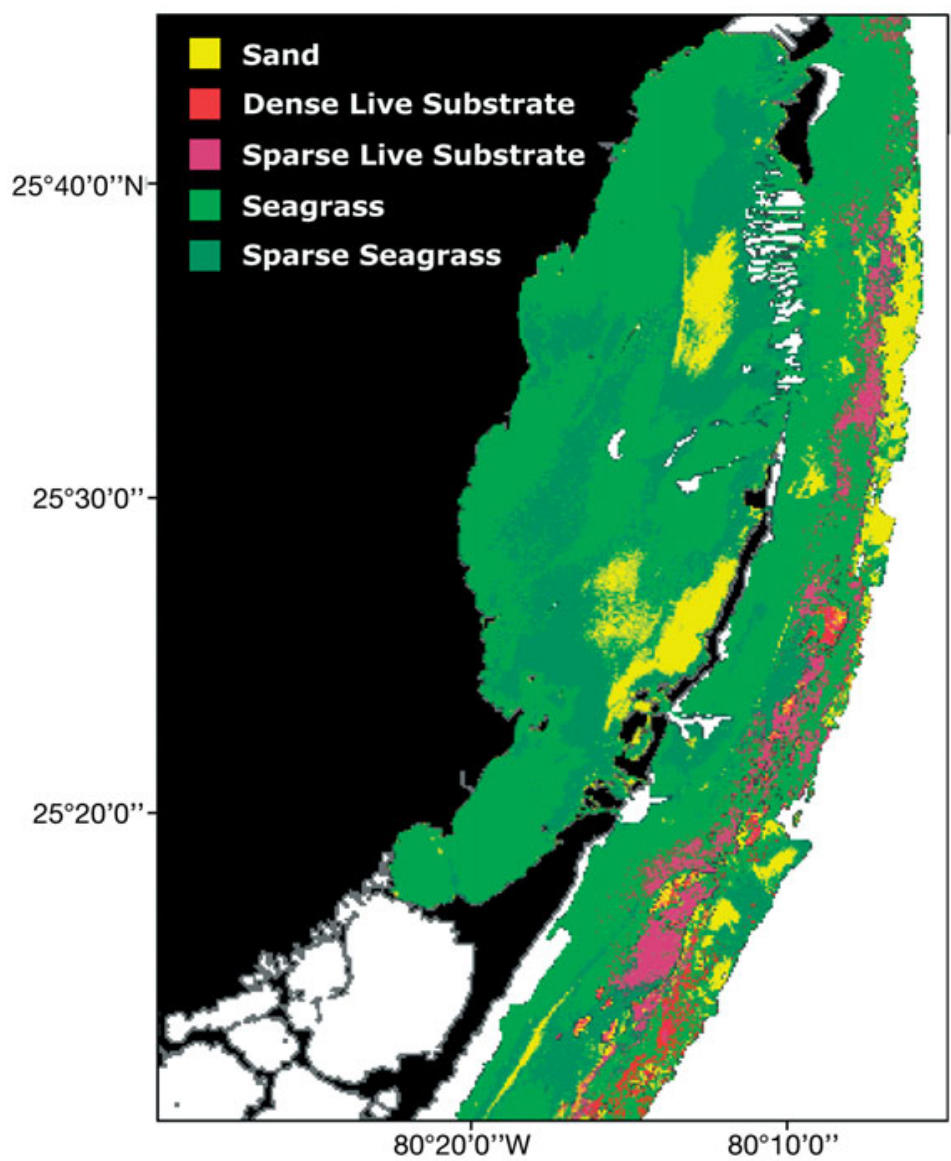

Fig. 4. Classification of the North Florida Reef Tract (NFRT) into the 5 biotopes used for this study based on a $30 \mathrm{~m}$ resolution Landsat 7 Enhanced Thematic Mapper Plus (ETM+) image. Overall accuracy exceeded $86 \%$ they are used here allows for stronger class separability, which should provide more accurate end classification in areas without precisely known depths or optical properties.

Because the classification of biotopes is the first step in an additive process to scale up metabolic values, errors in classification will propagate to subsequent calculations. Given the range of misclassifications exhibited across the MCRM classes, different training ROIs, and different classification algorithms, the relative impact on regional scale calculations is minimal. Analysis of error shows that the misclassification potential of the shelf terrace class (Fig. 3) would result in potential error ranges within the shelf terrace class of $\pm 1.2 \%, \pm 1.4 \%$, and $\pm 4.2 \%$ for $P, R$, and $G$ respectively. The potential for misclassification of the patch reef class was more dramatic, but because of the small area covered by that class $\left(0.71 \%\right.$ or about $19 \mathrm{~km}^{2}$ of the NFRT total area), even wide variances in classification would have had very small impacts on the predicted regional metabolic and carbonate parameter values.

Misclassification of individual pixels is more allowable when scaling up metabolic or carbonate parameters than it is in habitat classification, since the end result relies on the proportional relationships between the classes, rather than on their specific spatial distribution. This concept also applies to the differences between sensors. IKONOS imagery will detect much higher detail around variable areas, such as patch reefs, than will Landsat ETM+ imagery, and airborne sensors will have still higher performance for detection of small spatial scale variability. However, as long as the proportionality of biotopes remains constant or nearly so, the metabolic estimates will be the nearly the same. Thus, the use of MCRM classes as proxies for biotope variability and metabolic parameters can greatly simplify the process of scaling up measurements of carbonate production and carbon budgets over regional scales.

Our scaled up estimation shows the NFRT to be net heterotrophic $\left(E=-5.74 \times 10^{8} \mathrm{~kg} \mathrm{C} \mathrm{yr}^{-1}=\right.$ $-0.58 \mathrm{~g} \mathrm{C} \mathrm{m}^{2} \mathrm{~d}^{-1}$; Fig. 5). Our regional estimation by Landsat of excess production is very similar to the numbers based on results from a much higher-resolution $(1.5 \mathrm{~m})$ multispectral airborne sensor, the Advanced Imaging Spectrometer for Applications (AISA) (Brock et al. 2006), but is also arrived at by classifying imagery at a regional scale. However, this Landsat estimation of the notably heterotrophic $(P: R=0.84)$ condition of the NFRT is unlike some previous reports of metabolic values on Pacific atolls, which demonstrate that net excess production is usu- 


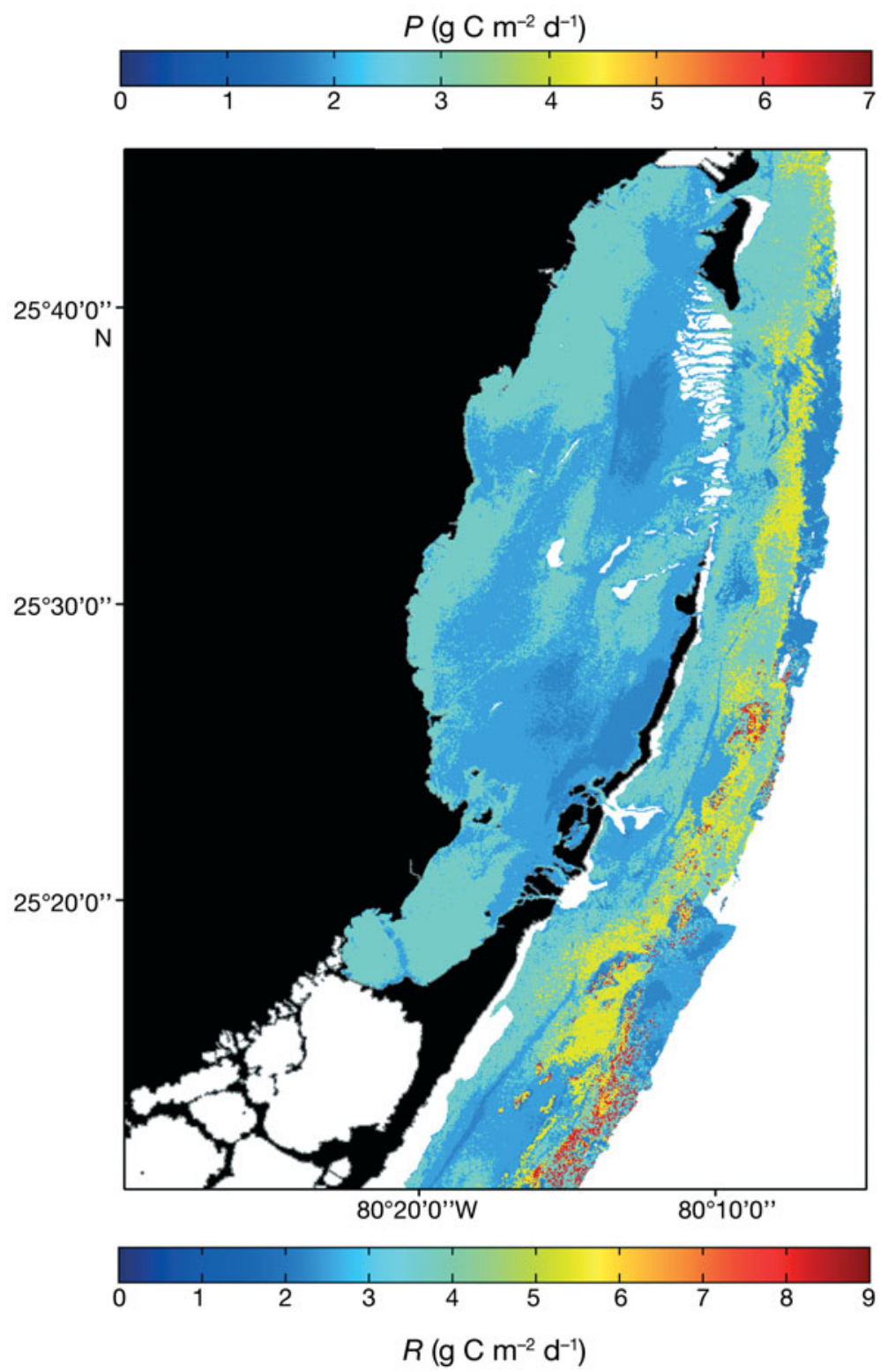

Fig. 5. Gross photosynthetic production $(P)$ and respiration $(R)$ estimates over the North Florida Reef Tract (NFRT). The highest rates of production and respiration are located in the patch reef and shelf terrace classes, but have a relatively patchy distribution across both classes. Note the different numerical values for the same colors between production and respiration. This scaling difference is possible here because of the consistent $P: R$ ratio of the biotopes applied here

ally near zero $(E \approx 0 ; P: R \approx 1)$ (Kinsey 1983), or even somewhat greater than zero (Atkinson \& Grigg 1984). This study suggests that the NFRT is a carbon sink at broad scales, producing about $15 \%$ less carbon than is needed by the system, supporting the smaller-scale assertions of Brock et al. (2006) at a regional scale.

The exercise of scaling up metabolic and calcification parameters is obviously fundamentally limited by the precision of measured metabolic values within a given biotope. Despite several decades of related research, it seems too often assumed that values from important earlier works do not change with time for a given community, habitat, or biotope, with the result that the metabolism, carbonate production, and $\mathrm{CO}_{2}$ air-sea flux of reefs remains poorly constrained in the face of increasing $\mathrm{pCO}_{2}$ and ocean acidification. One potential source of error in our assessment is the fact that the biotopes used here are broadly found throughout the NFRT, but were only directly measured in situ for metabolic parameters over a relatively small area of $\sim 0.5 \mathrm{~km}^{2}$. Greater spatial distribution of in situ observations of the same biotopes across the region would theoretically provide a more suitable dataset for scaling up.

Another potential source of error in these estimates lies in the values used for live coral cover, which directly impacts estimates of $G$. Here we adopted the Brock et al. (2006) dense live substrate biotope, which is distinct from NFRT patch reefs, being $\sim 7 \%$ live hermatypic coral cover. This number is close to the average live hermatypic coral cover of 6.6 to $7.5 \%$ reported across the entire Florida Keys National Marine Sanctuary (FKNMS) in 2000 to 2004 by the Coral Reef Evaluation \& Monitoring Program (CREMP 2005), but less than the 11 to $14 \%$ live coral cover reported for Upper Keys (including NFRT) patch reefs by the same program. Other observations of NFRT patch reefs around the same time by the Atlantic and Gulf Rapid Reef Assessment (AGRRA) program indicate an average live hard coral cover of $27 \%$ (SD $\pm 13 \%$ ) (Lang 2003, Marks 2007). Given this range of values to work with for live coral cover on regional patch reefs, it is possible that the productivity and carbonate precipitation of the NFRT have been underestimated in this analysis.

\section{Implications for ocean acidification}

The net calcification over the entire range of the NFRT, as defined here, was nearly zero $(G=-2 \times$ $10^{-3} \mathrm{~g} \mathrm{CaCO}_{3} \mathrm{~m}^{-2} \mathrm{~d}^{-1}$; Fig. 6), at only $\sim 3 \%$ the absolute value of $G$ reported by Brock et al. (2006). More importantly, however, our results indicate net dissolution (calcification deficit) over the scope of the NFRT. This is most likely a function of the inclusion here of the large areas of seagrass in the cross shelf class, which represent areas with net dissolution of carbonate as measured by the SHARQ ( $\left.G=-0.19 \mathrm{~g} \mathrm{C} \mathrm{m}^{-2} \mathrm{~d}^{-1}\right)$. This 


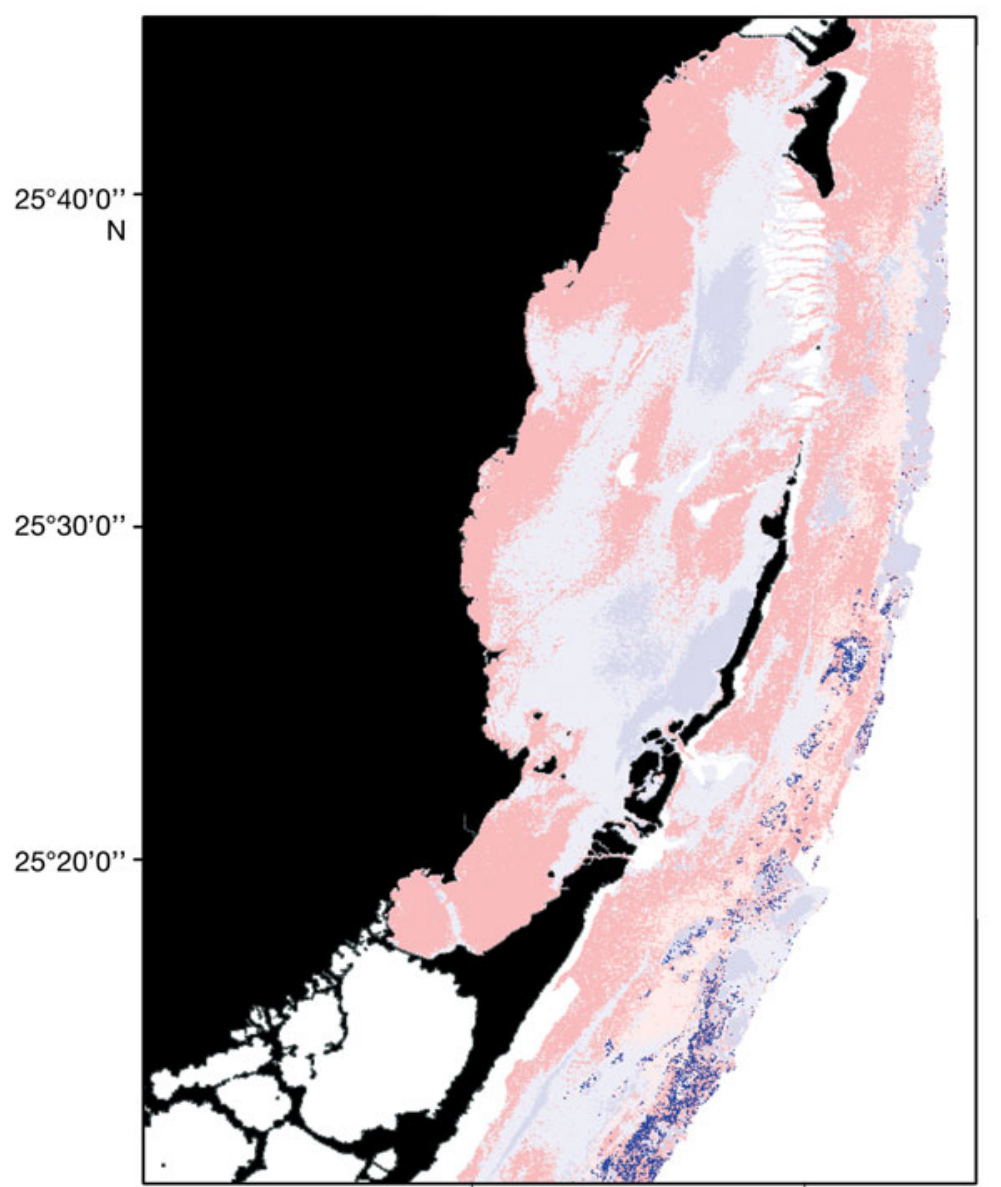

$80^{\circ} 20^{\prime} 0^{\prime \prime} \mathrm{W}$

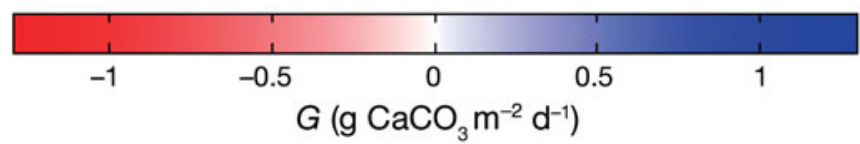

Fig. 6. Calcification $(G)$ estimates for the North Florida Reef Tract (NFRT). With the exception of the areas of dense live cover, most of the NFRT has net calcification rates near zero

agrees with observations by Burdige \& Zimmerman (2002) that the rates of dissolution in some carbonate sediments are directly proportional to the thickness of overlying seagrass beds. The delivery of $\mathrm{O}_{2}$ to surface sediments by the seagrass root system drives a corresponding increase in total inorganic carbon $\left(\Sigma \mathrm{CO}_{2}\right)$ and total alkalinity (TA), while decreasing $\mathrm{pH}$ (Burdige \& Zimmerman 2002).

By comparison, the smaller area of Brock et al. (2006) is proportionally covered with more dense live substrate $\left(G=1.29 \mathrm{~g} \mathrm{C} \mathrm{m}^{-2} \mathrm{~d}^{-1}\right)$. Based on this new regional estimate for carbonate dissolution over the range of the NFRT, we can approximate an annual sequestration of $753 \pm 2463$ (mean $\pm \mathrm{SD}$ ) metric tons of atmospheric $\mathrm{CO}_{2} \mathrm{yr}^{-1}$ across the NFRT. This sequestration value represents the net relationship between car- bonate dissolution $\left(\mathrm{CO}_{2}\right.$ sink) and heterotrophy and calcification (sources of $\mathrm{CO}_{2}$ ). The high standard deviation derives from error propagation of classification errors that yield the high relative standard deviation for $G$.

There is a reasonable possibility that our reported rate of dissolution is actually a substantial underestimate of the true rate. The measurements reported in Brock et al. (2006) were made in the most ocean-influenced part of our study area, but there is a known shallow phreatic aquifer and increasing groundwater discharge through sediments as one moves landward in Biscayne Bay (Wang et al. 2003). The mixing of fresh and salt waters drives the saturation state of carbonate mineral phases to a state of undersaturation $(\Omega<1)$ (Morse \& Mackenzie 1990). Thus, a combination of already undersaturated pore waters and the additional increase in TA and $\Sigma \mathrm{CO}_{2}$ resulting from the addition of $\mathrm{O}_{2}$ by overlying seagrass likely means that there is actually more dissolution in the majority of the backreef area of the NFRT than is reflected by our estimates in this manuscript.

At the scales required for ecosystem-based management and regional implications of ocean acidification, it is necessary to represent the full range of biotope spatial variability when assessing coral reef metabolism or carbonate production over larger areas. A regional estimate made by scaling up over only a small area can potentially have large errors when expanded to greater scales based only on area, but not biotope variability. For example, the area surveyed by Brock et al. (2006) was proportionally much higher in cover by dense live substrate than the entire NFRT region defined in this work, resulting in negative calcification values for the present work, despite similar values for $P$ and $R$ between the 2 studies.

The difference between the small- and large-scale estimates for carbonate production is substantial. The change from a multi-sensor mean of $G=0.16 \pm 0.14 \mathrm{~g}$ $\mathrm{CaCO}_{3} \mathrm{~m}^{-2} \mathrm{~d}^{-1}$ and 'best value' from corrected AISA data of $G=0.07 \mathrm{~g} \mathrm{CaCO}_{3} \mathrm{~m}^{-2} \mathrm{~d}^{-1}$ (Brock et al. 2006) to the Landsat NFRT-wide value reported here of $G=$ $-0.002 \mathrm{~g} \mathrm{CaCO}_{3} \mathrm{~m}^{-2} \mathrm{~d}^{-1}$ represents an important difference from net calcification to net dissolution. However, both net values are very close to zero, indicating a regional reef environment that is very likely in equilibrium between calcification and dissolution on time scales that encompass seasonal and interannual variability in carbonate production. However, with continued decline of dense live substrate on the more pro- 
ductive reefs Florida Keys (Palandro et al. 2008) and increasing ocean acidification (Kleypas et al. 2006) it is likely that the carbonate production values $(G)$ for the NFRT will decline in the coming century.

By comparison with Moorea (French Polynesia), the entire $2711 \mathrm{~km}^{2}$ NFRT could be thought of as producing $-1 \%$ of the total amount of carbonate precipitated over only $35 \mathrm{~km}^{2}$ of Moorea reef (Andréfouët \& Payri 2001). The estimated net dissolution across the NFRT has important implications for modeling buffering responses at ecosystem scales in the Florida Keys, something that can not be achieved as well when scaling up from mesocosm experiments.

Part of the ecological challenge for the NFRT in an environment of decreasing $\mathrm{pH}$ is that the areas with the highest carbonate production (patch reefs) make up just under $1 \%$ of the area of what is defined here as the NFRT. On the other hand, the seagrass dominated cross shelf class, which has net carbonate dissolution, represents $\sim 78 \%$ of the area for the NFRT. Compare this to Moorea, where $\sim 49 \%$ of the area studied (MidBarrier class) had carbonate production values of $G \approx$ $18 \mathrm{~g} \mathrm{CaCO}_{3} \mathrm{~m}^{-2} \mathrm{~d}^{-1}$ (Andréfouët \& Payri 2001).

It can be inferred that in order to offset current regional rates of net dissolution, NFRT patch reefs, at their current spatial extent, would have to produce $\sim 2.5$ times as much carbonate as currently estimated, or as a geomorphologic class, nearly $G \approx 0.75 \mathrm{~g} \mathrm{CaCO}_{3}$ $\mathrm{m}^{-2} \mathrm{~d}^{-1}$. This increase in calcification could be accommodated by a proportional increase in live hermatypic coral cover from the $7 \%$ reported by Brock et al. (2006) and used for calculations in this work, to $\sim 18 \%$ live coral cover. A similar increase in coral cover across the scope of the shelf terrace class could result in a significant change across the NFRT to a hypothetical net carbonate production of $G \approx 0.08 \mathrm{~g} \mathrm{CaCO}_{3} \mathrm{~m}^{-2} \mathrm{~d}^{-1}$. While such an increase is improbable given current coral reef trends (Hoegh-Guldberg 1999, Gardner et al. 2003), this kind of information from scaling up in situ production data can be very useful to both modelers and managers.

Kleypas et al. (1999) predict decreases in biogenic aragonite precipitation of between 14 and $30 \%$ by the middle of this century. Taking the worst case scenario of a $\sim 30 \%$ decrease in production of reef carbonate and using the scaled-up carbonate production values reported here, some habitat area based estimates of the response of the NFRT to ocean acidification are possible. Without taking into account factors such as water retention time or changes in sea surface temperature (SST), ocean acidification could decrease the net calcification across the NFRT to $G \approx-0.05 \mathrm{~g} \mathrm{CaCO}_{3} \mathrm{~m}^{-2}$ $\mathrm{d}^{-1}$, a full order of magnitude more net carbonate dissolution than current estimates. With the projected $30 \%$ decrease in biotic aragonite production (Kleypas et al. 1999), the NFRT can be predicted to increase its function as a $\mathrm{CO}_{2}$ sink to about 22000 metric tons of $\mathrm{CO}_{2}$ per year. Use of the spatial estimates from this method to parameterize models that include SST, water retention time, light, more sophisticated biogeochemical functions, and other factors could provide improved estimates of the anticipated regional impacts of continued ocean acidification.

\section{CONCLUSIONS}

Well-classified Landsat 7 ETM+ imagery, combined with the MCRM provides a robust tool for scaling up in situ measurements of coral reef metabolism to regional scales. With the ability demonstrated here to estimate regional metabolic values when classifications are performed per geomorphologic class, even without water column corrections, this approach provides a uniform method by which to begin to refine global estimates of reef productivity. Truly global estimates are often too expensive to achieve with the much higher costs per area for other high resolution sensors. However, this technique cannot be scaled up to global estimates of carbonate systems and metabolic values without accurate contemporary in situ observations strategically spread throughout the global coral reef systems.

We report here that the NFRT is a net sink for atmospheric $\mathrm{CO}_{2}$, but for only $\sim 753$ metric tons $\mathrm{yr}^{-1}$ due to the near balance between carbonate precipitation in the dense live substrate of the patch reef class and the net dissolution over the surrounding large areas of seagrass. This study supports previous work by Brock et al. (2006) over a smaller region, suggesting that the NFRT does act as a net regional sink for carbon. Application of the spatial estimates from this method to parameterize more sophisticated physical and biogeochemical models could provide improved estimates of regional impacts of continued ocean acidification in any area with reliable in situ carbon and carbonate production data.

Managers are becoming more aware of the need to manage ecosystems, not just communities, through ecosystem-based management (Gell \& Roberts 2003, Lotze et al. 2006). Using Landsat imagery to estimate coral reef carbonate production over large scales, as described here, also provides a tool for managers faced with ecosystem-scale decisions regarding reef metabolism and critical issues of impacts of ocean acidification and environmental variability.

Acknowledgements. This work was supported by a grant from NASA (\#NNG04GO90G). Special thanks to D. Palandro and K. Yates for expert consultations at several stages of this project. Thanks also to 3 anonymous reviewers for their constructive suggestions for improvement of this manuscript. 


\section{LITERATURE CITED}

Andréfouët S, Payri C (2001) Scaling-up carbon and carbonate metabolism of coral reefs using in-situ data and remote sensing. Coral Reefs 19:259-269

- Andréfouët S, Müller-Karger FE, Hochberg EJ, Hu C, Carder KL (2001) Change detection in shallow coral reef environments using Landsat 7 ETM+ data. Remote Sens Environ 78:150-162

Andréfouët S, Kramer P, Torres-Pulliza D, Joyce KE and others (2003) Multi-site evaluation of IKONOS data for classification of tropical coral reef environments. Remote Sens Environ 88:128-143

Andréfouët S, Muller-Karger FE, Robinson JA, Kranenburg CK, Torres-Pulliza D, Spraggins SA, Murch B (2006) Global assessment of modern coral reef extent and diversity for regional science and management applications: A view from space. Proc 10th Intl Coral Reef Symp (Okinawa):1732-1745

Atkinson MJ, Grigg RW (1984) Model of a coral-reef ecosystem 2: Gross and net benthic primary production at French Frigate Shoals, Hawaii. Coral Reefs 3:13-22

Brock JC, Yates KK, Halley RB, Kuffner IB, Wayne Wright C, Hatcher BG (2006) Northern Florida reef tract benthic metabolism scaled by remote sensing. Mar Ecol Prog Ser 312:123-139

Burdige DJ, Zimmerman RC (2002) Impact of sea grass density on carbonate dissolution in Bahamian sediments. Limnol Oceanogr 47:1751-1763

Capolsini P, Andréfouët S, Rion C, Payri C (2003) A comparison of Landsat ETM+, SPOT HRV, IKONOS, ASTER, and airborne MASTER data for coral reef habitat mapping in south pacific islands. Can J Rem Sens 29:187-200

CREMP (2005) 2004 Coral Reef Evaluation \& Monitoring Project Annual Report, Florida Fish and Wildlife Conservation Commission, St. Petersburg, FL

> Dustan P, Dobson E, Nelson G (2001) Landsat thematic mapper: Detection of shifts in community composition of coral reefs. Conserv Biol 15:892-902

Feely RA, Sabine CL, Lee K, Berelson W, Kleypas J, Fabry VJ, Millero FJ (2004) Impact of anthropogenic $\mathrm{CO}_{2}$ on the $\mathrm{CaCO}_{3}$ system in the oceans. Science 305:362-366

Fine M, Tchernov D (2007) Scleractinian coral species survive and recover from decalcification. Science 315:1811

Franklin JL, Avila LA, Beven JL, Lawrence MB, Pasch RJ, Stewart SR (2001) Atlantic hurricane season of 2000. Mon Weather Rev 129:3037-3056

> Gardner TA, Cote IM, Gill JA, Grant A, Watkinson AR (2003) Long-term region-wide declines in Caribbean corals. Science 301:958-960

Gattuso JP, Buddemeier RW (2000) Calcification and $\mathrm{CO}_{2}$. Nature 407:311-313

- Gattuso JP, Frankignoulle M, Pichon M, Delesalle B, Canon C (1996) Carbon fluxes in coral reefs: I. Lagrangian measurement of community metabolism and resulting air-sea $\mathrm{CO}_{2}$ disequilibrium. Mar Ecol Prog Ser 145:109-121

> Gattuso JP, Frankignoulle M, Bourge I, Romaine-Lioud S, Buddemeier RW (1998a) Effect of calcium carbonate saturation of seawater on coral calcification. Global Planet Change 18:37-46

Gattuso JP, Frankignoulle M, Wollast R (1998b) Carbon and carbonate metabolism in coastal aquatic ecosystems. Annu Rev Ecol Syst 29:405-434

> Gell FR, Roberts CM (2003) Benefits beyond boundaries: the fishery effects of marine reserves. Trends Ecol Evol 18: 448-455

Hatcher BG (1997) Coral reef ecosystems: how much greater is the whole than the sum of the parts? Coral Reefs 16: S77-S91

Hoegh-Guldberg O (1999) Climate change, coral bleaching and the future of the world's coral reefs. Mar Freshw Res 50:839-866

Hoegh-Guldberg O (2005) Low coral cover in a high- $\mathrm{CO}_{2}$ world. J Geophys Res Oceans 110, C09S06, doi:10.1029/ 2004JC002528

> Hughes TP, Baird AH, Bellwood DR, Card M and others (2003) Climate change, human impacts, and the resilience of coral reefs. Science 301:929-933

Ikeda Y, Hata H, Suzuki A, Kayanne H (1997) Diurnal carbon flux at the barrier reef in Palau. Proc 8th Intl Coral Reef Symp (Panama) 1:965-970

Jensen JR (2004) Introductory digital image processing. Prentice Hall, Upper Saddle River, NJ

Kayanne H, Suzuki A, Saito H (1995) Diurnal changes in the partial pressure of carbon dioxide in coral reef water. Science 269:214-216

Kinsey DW (1978) Alkalinity changes and coral reef calcification. Limnol Oceanogr 23:989-991

Kinsey DW (1983) Standards of performance in coral reef primary production and carbon turnover. In: Barnes DJ (ed) Perspectives on coral reefs. Australian Institute of Marine Science, Townsville, p 209-218

Kinsey DW (1985) Metabolism, calcification and carbon production I: Systems level studies. Proc 5th Intl Coral Reef Symp (Tahiti) 4:505-526

> Kleypas JA, Buddemeier RW, Archer D, Gattuso JP, Langdon C, Opdyke BN (1999) Geochemical consequences of increased atmospheric carbon dioxide on coral reefs. Science 284:118-120

Kleypas JA, Buddemeier RW, Gattuso JP (2001) The future of coral reefs in an age of global change. Int J Earth Sci 90: 426-437

Kleypas J, Feely RA, Fabry VJ, Langdon C, Sabine C, Robbins LL (2006) Impacts of ocean acidification on coral reefs and other marine calcifiers: a guide for future research. NSF, NOAA, and the USGS, St. Petersburg, FL

Kuffner IB, Andersson AJ, Jokiel PL, Rodgers KS, Mackenzie FT (2007) Decreased abundance of crustose coralline algae due to ocean acidification. Nature Geoscience 1: $114-117$

Lang JC (ed) (2003) Status of coral reefs in the western Atlantic: Results of initial surveys, Atlantic and Gulf Rapid Reef Assessment (AGRRA) program, Vol 496, Washington, $\mathrm{DC}$

Lotze HK, Lenihan HS, Bourque BJ, Bradbury RH and others (2006) Depletion, degradation, and recovery potential of estuaries and coastal seas. Science 312:1806-1809

Marks KW (2007) AGRRA Database, version (10/2007)

Morse JW, Mackenzie FT (1990) Geochemistry of sedimentary carbonates, Vol 48. Elsevier, Amsterdam

> Mumby PJ, Edwards AJ (2002) Mapping marine environments with IKONOS imagery: enhanced spatial resolution can deliver greater thematic accuracy. Remote Sens Environ 82:248-257

Orr JC, Fabry VJ, Aumont O, Bopp L and others (2005) Anthropogenic ocean acidification over the twenty-first century and its impact on calcifying organisms. Nature 437:681-686

Ouillon S, Douillet P, Andréfouët S (2004) Coupling satellite data with in situ measurements and numerical modeling to study fine suspended-sediment transport: A study for the lagoon of New Caledonia. Coral Reefs 23:109-122

> Palandro D, Andréfouët S, Dustan P, Müller-Karger FE (2003a) Change detection in coral reef communities using 
IKONOS satellite sensor imagery and historic aerial photographs. Int J Remote Sens 24:873-878

Palandro D, Andrefouet S, Muller-Karger FE, Dustan P, Hu CM, Hallock P (2003b) Detection of changes in coral reef communities using Landsat-5 TM and Landsat-7 ETM+ data. Can J Rem Sens 29:201-209

Palandro D, Andréfouët S, Hu C, Hallock P and others (2008) Quantification of two decades of coral reef habitat decline in the Florida Keys National Marine Sanctuary using Landsat data (1984-2002). Remote Sens Environ 112: 3388-3399

Pandolfi JM, Bradbury RH, Sala E, Hughes TP and others (2003) Global trajectories of the long-term decline of coral reef ecosystems. Science 301:955-958

Smith SV, Buddemeier RW (1992) Global change and coral reef ecosystems. Annu Rev Ecol Syst 23:89-118

Smith SV, Kinsey DW (1976) Calcium-carbonate production, coral-reef growth, and sea-level change. Science 194: 937-939

Suzuki A, Kawahata H, Goto K (1997) Reef water $\mathrm{CO}_{2}$ system and carbon cycle in Majuro Atoll, the Marshall Islands in the central Pacific. Proc 8th Intl Coral Reef Symp (Panama) 1:971-976

Torres-Pulliza D (2004) A multi-sensor comparison for coral reef habitat mapping: A case study using a tropical patch reef environment in Biscayne National Park, Florida. MSc

Editorial responsibility: Alain Vézina, Dartmouth, Nova Scotia, Canada thesis, University of South Florida, Tampa, FL

- Vecsei A (2004) A new estimate of global reefal carbonate production including the fore-reefs. Global Planet Change 43:1-18

Wabnitz CCC, Andréfouët S, Torres-Pulliza D, Muller-Karger FE, Kramer P (2008) Regional-scale seagrass habitat mapping in the Wider Caribbean region using Landsat sensors: applications to conservation and ecology. Remote Sens Environ 112:3455-3467

Walther GR, Post E, Convey P, Menzel A and others (2002) Ecological responses to recent climate change. Nature 416:389-395

Wang JD, Luo JG, Ault JS (2003) Flows, salinity, and some implications for larval transport in South Biscayne Bay, Florida. Bull Mar Sci 72:695-723

> Ware JR, Smith SV, Reaka-Kudla ML (1992) Coral reefs: Sources or sinks of atmospheric $\mathrm{CO}_{2}$. Coral Reefs 11: $127-130$

Yates KK, Halley RB (2003) Measuring coral reef community metabolism using new benthic chamber technology. Coral Reefs 22:247-255

Yates $\mathrm{KK}$, Halley RB (2006) $\mathrm{CO}_{3}{ }^{2-}$ concentration and $\mathrm{pCO}_{2}$ thresholds for calcification and dissolution on the Molokai reef flat, Hawaii. Biogeosciences Discuss 3:123-154

Zeebe RE, Wolf-Gladrow D (2003) $\mathrm{CO}_{2}$ in seawater: Equilibrium, kinetics, isotopes, Vol 65. Elsevier, Amsterdam

Submitted: November 13, 2007; Accepted: January 8, 2009 Proofs received from author(s): March 30, 2009 